\title{
With Whom Do We Speak? Building Transdisciplinary Collaborations in Rhetoric of Science
}

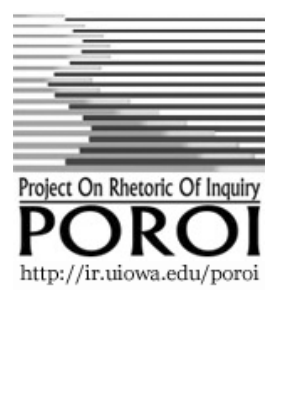

\author{
Caroline Gottschalk Druschke \\ University of Rhode Island \\ Kingston, RI
}

Poroi 10,1(January 2014)

In the 2013 Poroi special issue celebrating the Association for the Rhetoric of Science \& Technology's (ARST) 20 th anniversary, Leah Ceccarelli questioned rhetoricians' engagement with the world at large asking, "To whom do we speak?" Referring to the axiom that there are "two modes by which rhetoricians can have an impact on the world around us - through our teaching and through our extradisciplinary service," Ceccarelli insisted that rhetoricians of science are already engaged in these kinds of work, but demanded, "we need to think more and talk more about how we do this work so that we can help each other more effectively transform our scholarly findings into meaningful action in these fora."

This call, to "more effectively transform our scholarly findings into meaningful action," was at the heart of J ean Goodwin's proposal to convene a roundtable featuring "Collaborations between scientists and rhetoricians of science/ technology/medicine" at the Association for the Rhetoric of Science \& Technology November 2013 preconference, the forum from which this paper emerged. It is a call I try to answer in this paper, though I do so by looking beyond the confines of teaching and extradisciplinary service, the realms of those students and civic actors to whom Ceccarelli suggested we should be speaking. Instead, I here describe three funded research collaborations that offered opportunities to speak with students, civic actors, science researchers, and policymakers in collaborative, constructive, and constitutive ways.

The three collaborations I pull from include my roles as: 1) a Ph.D. student in a National Science Foundation Integrative Graduate Education and Research Traineeship (IGERT) training program; 2) a faculty mentor 
in the Summer Undergraduate Research Fellows program, funded by National Science Foundation's Experimental Program to Stimulate Competitive Research; and 3) a research fellow with the Environmental Protection Agency's (EPA) Atlantic Ecology Division.

Taken together, these collaborations represent something like Herndl and Cutlip's (2013) "applied rhetoric of science," and heed their advice to "move from talking about science to doing science." Rather than adopt the deficit model of science communication, these collaborations spring from a contextual model (Gross, 1994): a deliberative model of science communication that encourages multiple kinds of actors with multiple kinds of expertise to engage with one another and determine a course of action. In other words, the collaborations described here position scientists and rhetoricians of science as co-constructors of engaged science that gets things done in the world. And so, while it is important to focus on what rhetoric can offer to the scientific community and what rhetoricians gain in the exchange - our assigned task for the ARST roundtable - it is even more important to think beyond a transactional model of collaboration. This shift calls us to turn the focus away from exchange (what science gains from rhetoric and vice versa) and towards conceiving of our work as a necessary and integral part of the engaged practice of science itself.

My work in applied rhetoric of science began when I was accepted into the Landscape, Ecological and Anthropogenic Processes (LEAP) training program while I was a Ph.D. student in the Department of English at the University of Illinois at Chicago. Running from 2006 to 2012, LEAP was one of the National Science Foundation's Integrative Graduate Education and Research Traineeships (NSF-IGERT). NSF-IGERTs provide competitive fellowships to $25 \mathrm{Ph}$.D. candidates over a five-year period, and support development of an accompanying broad-based curriculum. The program is intentionally interdisciplinary, with strong emphases on collaboration, problem-based learning, teamwork, and practical internships.

This particular IGERT centered on ecological processes in humanaltered landscapes, drawing students mostly from ecology and environmental engineering; I was the first humanities student accepted into the program. For two years, IGERT trainees receive $\$ 30,000 /$ year stipends, plus travel and supply money, a tuition waiver, and a teaching release. They take coursework in graduate level natural and social sciences, complete an internship, and design and execute a collaborative 
capstone project. (The triumphs and tribulations of our participatory capstone project, a citizen science study of bee diversity and abundance in the Chicago area, is described in detail in Druschke \& Seltzer, 2012.) IGERT training is rigorous, interdisciplinary, and practical.

That program changed the course of my career. I had already started doing fieldwork when I applied for LEAP-IGERT, interviewing individuals involved with sustainable agriculture in the Midwest. I was a rhetorician trained in materiality, but I really had no idea how little I understood about the material environment. I wanted to understand people's commitment and engagement to a variety of places, processes, and ecosystems, but as I came to realize I understood very little about what they were engaged in and committed to.

Because of LEAP, I completed a dissertation with a heavy emphasis on both the material and symbolic aspects of watershed-based conservation, a project that represented collaborations with conservation staff, local stakeholders, and faculty from agricultural economics and geography; it built from rhetorical analyses of qualitative interviews and statistical analyses of a watershed-wide survey; it focused on implications for both rhetorical theory and conservation outreach; and it blossomed into subsequent articles (Druschke, 2011; Druschke, 2013; Druschke \& Secchi, 2014).

Through LEAP, I gained some crucial knowledge: I learned how much I do not know; I learned how to evaluate scientific arguments; and I learned how to have substantive and productive conversations with colleagues from across the aisle. LEAP also gave me the chance to refine my answers to continued questions about what I do, how I do it, and why my work matters.

The experience, I am sure, also helped me land my tenure track position at the University of Rhode Island, where I learned about Rhode Island NSF-EPSCoR (Experimental Program to Stimulate Competitive Research). This \$20 million, 5-year award brings together nine of Rhode Island's institutions of higher education to foster collaborations that will increase research competitiveness in the areas of marine science and climate change. In summer 2012, I applied to mentor two undergraduates on a 10-week research study as part of EPSCoR's Summer Undergraduate Research Fellows (SURF) program, which provides each student a $\$ 4000$ stipend and $\$ 500$ in research funds to work with a faculty mentor on a research project. 
Summer 2012 was the first time that the SURF program was open to communication projects, and I was the only communication researcher in Rhode Island to propose one. While I failed to anticipate the work involved in explaining to SURF mentors and students why our field should be represented, colleagues' constant lack of familiarity with rhetoric offered a great opportunity for scrutinizing the value of a rhetorical approach. As I learned to explain: rhetoric offers a useful perspective on the scientific endeavor; rhetoric complicates and contextualizes the practice of science and its translation into policy; rhetoric adds necessary - even ethical - depth, complication, and nuance to the communication of scientific results and to perspectives on public engagement with science.

I also did not anticipate that the powers-that-be (understandably operating from a "deficit model") would not always understand that communication researchers are capable of posing research questions, rather than just delivering the results of someone else's research. SURF explicitly tasked me with addressing the question: "How can scientific findings and forecasts in the area of climate variability and marine life be made more accessible to the public through a variety of media?" It was a question that focused more on the dissemination of knowledge, and less on a nuanced rhetorical vision of the give and take of knowledge and understanding. I did my best to design a project around it: a project that attended to communication between Rhode Island's marine science community and its commercial fishermen. But our research very quickly provided evidence for adopting a contextual model of rhetoric, rather than a deficit model. We discovered from our interviewees that the issue of making scientific findings more accessible did not get at the more pressing, practical, and interesting issues of scientific knowledge creation and the relationship between science, publics, and policy in fishermen's daily lives. The fishermen we spoke with were not concerned about the inaccessibility of scientific findings. Rather, they were concerned about how to insert themselves and their observations into the research endeavor, how to respond to climatic changes on a day-to-day basis, and whether current regulations would allow them to respond. This more nuanced finding has deep implications for actual policy.

In the end, the SURF experience was a large amount of labor that offered some important lessons. I learned to examine the underpinnings of a research question and address what I refer to as "deep communication": questions of engagement and deliberation rather than questions of content delivery. I learned that oftentimes my colleagues in the sciences have had 
no exposure to the field of rhetoric and need to be educated about what it (and I) can do, and that these same colleagues, once educated, are often enthusiastic, supportive, and grateful collaborators. I also learned that while colleagues in rhetoric and in the humanities more broadly are often enthusiastic about the idea of interdisciplinary collaborations, they do not always understand or value the modes of working in the sciences. Even supportive colleagues may not understand the time and labor involved in collecting data, hashing out disciplinary perspectives with potential colleagues, and establishing roles for rhetoric in the practice of science more generally.

I carried the lessons learned from LEAP and SURF into my current two-year research fellowship with the Environmental Protection Agency's Atlantic Ecology Division (AED). In summer 2013, I worked with a geographer at AED to interview local, state, and federal land managers about urban restoration and public interaction. That data will inform the development of a tool that will help land managers and local stakeholders prioritize and justify funding for wetlands restoration projects in urban watersheds, which is the immediate deliverable that EPA wants from the project.

We are also in the early stages of developing a series of wide-ranging articles with the rest of our research team, including an environmental economist and a research biologist. Our group is taking a transdisciplinary approach to our work, what Debra Hawhee (2009) has described as a perspective that attempts "to suspend - however temporarily - one's own disciplinary terms and values in favor of a broad, open, multilevel inquiry" (3); one "marked by shared interest in a particular matter or problem but often draw[ing] together radically different approaches" (3). We are attending to themes like ecosystem services, adaptive management, topoi of restoration, and public engagement. Together, we review transcripts, refine our research questions, discuss theoretical and practical deliverables, and plan out future projects. One year after we began, we are just starting to reap the benefit of the labor spent figuring out where each team member was coming from, how we could talk with one another, and how to engage in a project that was interesting, useful, and consequential for all of us.

This work, I think, is my best to date, and I hope it serves as a model for the types of collaborations we could be trying to form: collaborations that foster deep, sustained interdisciplinary and transdisciplinary conversations; that yield practical, necessary tools for environmental 
management; that inform theoretical concerns that span and contribute to our related disciplines; that serve - by their very existence - as forms of outreach and education about what a rhetorician can really offer, especially when she is involved in a project from the earliest stages of research design. This project has taken me - symbolically and materially away from a more traditional or academic view of the study of rhetoric. But it feels like I belong right where I am: making use of rhetoric in a transdisciplinary team to explore deep and consequential questions about the actual practice of environmental management.

I am trying to work in the uncomfortable but often productive space between rhetoric and science, and I encourage other rhetoricians of science to do the same. We can suspend belief in the boundary drawn between rhetoric and science and conceive of a future where rhetoric of science becomes an integral part of the practice of science itself. We can decide that the practice of rhetoric of science in these types of mutually beneficial - even civically beneficial - partnerships is an implicit characteristic of our field. Some might suggest it would diminish the structural integrity of rhetoric to cross that bridge into the scientific community. But, as Bender and Wellbery have described, rhetoric itself is a "transdisciplinary field of practice and intellectual concern" (25): a transdisciplinary, emplaced, engaged field by its very nature. In light of that, it may be time to think of rhetoric in a more expansive, collaborative, and consequential way.

\section{REFERENCES}

Bender, J.B., \&Wellbery, D.E. (1990). The ends of rhetoric: History, theory, practice. Redwood City: Stanford University Press.

Ceccarelli, L. (2013). To whom do we speak? The audiences for scholarship on the rhetoric of science and technology. Poroi, 9. Retrieved from http://ir.uiowa.edu/cgi/viewcontent.cgi?article=1151\&context=poroi

Druschke, C.G. (2011). Watershed: Conserving a common-place. (Doctoral dissertation). Retrieved from http://indigo.uic.edu/bitstream/handle/10027/8270/Druschke_Caroline.pdf? sequence $=1$ 
Druschke, C.G. (2013). Watershed as common-place: Communicating for conservation at the watershed scale. Environmental Communication: AJ ournal of Nature and Culture, 7, 80-96.

Druschke, C.G., \& Secchi, S. (2014). The impact of gender on agricultural conservation knowledge and attitudes in an Iowa watershed. J ournal of Soil and Water Conservation, forthcoming.

Druschke, C.G., \& Seltzer, C.S. (2012). Failures of engagement: Lessons learned from a citizens science pilot study. Applied Environmental Education \& Communication, 11, 178-188.

Gross, A.G. (1994). The roles of rhetoric in the public understanding of science. Public Understanding of Science, 3, 3-23.

Hawhee, D. (2009). Moving bodies: Kenneth Burke at the edges of language. Columbia: University of South Carolina Press.

Herndl, C.G., \& Cutlip, L.L. (2013). “How can we act?” A praxiographical program for the Rhetoric of Technology, Science, and Medicine. Poroi, 9. Retrieved from http://ir.uiowa.edu/cgi/viewcontent.cgi?article=1163\&context=poroi 